\title{
Mesoglein differences between two jellyfish populations of the genus Aurelia
}

\author{
Anastasiya V. Kotova $\cdot$ Oleg A. Kovtun • \\ Olga I. Podgornaya $\cdot$ Leonid S. Adonin
}

Received: 3 October 2014/ Accepted: 13 February 2015/Published online: 12 March 2015

(C) The Author(s) 2015. This article is published with open access at Springerlink.com

\begin{abstract}
The medusa, Aurelia aurita (Scyphozoa, Cnidaria), is counted as a cosmopolitan species with a worldwide distribution in most seas, from the poles to the tropics. Cnidarian is thought to possess two tissue layers: endoderm (gastroderm) and ectoderm, which are separated by huge mesoglea in medusa. The main medusas' morphology is similar in different populations. Previously the new protein "mesoglein" was determined as one of the main components of mesoglea. Deduced amino acid sequence of mesoglein contains Zona Pellucida (ZP) domain. The comparison of mesoglein and its gene from three habitats White Sea (WsA), Black Sea (BsA), Japonic Sea (JsA) has been done in the current work. The set of the mesoglea protein bands after SDS-PAGE is similar in all samples. Nevertheless, JsA mesogleins' $M_{r}$ is $53155 \mathrm{kDa}$, while WsA and BsA mesogleins have $M_{r}$ of $47 \mathrm{kDa}$. Antibodies raised against WsA mesoglein recognize only mesoglein with $M_{r}$ of $47 \mathrm{kDa}$, but not $53155 \mathrm{kDa}$, both on immunoblot and immunocytochemistry. Mesogleal cells and "elastic" fibrils are stained intensively in the mesoglea both from WsA and BsA but not from JsA. The possibility of gene diversity was checked by PCR with primers specific for WsA mesoglein gene. PCR products of expected length were obtained on cDNA from polyA-RNA template from mesogleal cells of WsA and BsA medusa but not on cDNA of JsA medusa. Our results evidence that there are two different species in genus Aurelia: Aurelia aurita inhabits White and Black Seas while Aurelia sp.1 inhabits Japonic Sea. Such a suggestion is in agreement with the one previously done on the base of comparison by other molecular biology methods.
\end{abstract}

Keywords Aurelia aurita $\cdot$ Jellyfish $\cdot$ Mesoglein $\cdot$ Evolution

\section{Introduction}

Cnidaria is one of the most ancient animal groups which arose $\sim 550$ millions year ago during the Cambrian explosion. Cnidaria are aquatic organisms. Some of the Cnidaria representatives inhabit fresh or less salted

A. V. Kotova · O. I. Podgornaya · L. S. Adonin $(\bowtie)$

Institute of Cytology RAS, St. Petersburg, Russia

e-mail: leo.adonin@gmail.com

O. A. Kovtun

Hydrobiological Station of Odessa National I. I. Mechnikov University, Odessa, Ukraine

O. I. Podgornaya $\cdot$ L. S. Adonin

Department of Cytology and Histology, Faculty of Biology and Soil Sciences, St-Petersburg State University, St.Petersburg, Russia 
water, but the vast majority is the marine animals, which populated ocean waters from littoral up abyssal deeps both in plankton and in benthos (Dogel 1981). Cnidarians were for a long time grouped with Ctenophores in the phylum Coelenterata, but increasing awareness of their differences caused them to be placed in separate phyla (Daly et al. 2007). The defining Cnidarian feature is their possession of stinging cells, or cnidocytes, which is used for feeding (Kayal et al. 2013). Cnidarian is thought to possess two tissue layers: endoderm (gastroderm) and ectoderm, which are separated by mesoglea in medusa (Chapman 1974; Dogel 1981). The cnidarian radiation is relatively modest, giving rise to two major body plans (polyp and medusa) and some ten thousand extant species. The main difference between polyp and medusa is the degree of the mesoglea development. Aurelia aurita mesoglea contains a number of mesogleal cells (Mc). This feature is not unique but rather rare (Chapman 1966). Mesoglea, with its mesogleal cells, acquires a similarity with the connective tissues, derivate of mesoderm, of more advanced animals (Hyman 1940; Chapman 1974; Arai 1997).

Genus Aurelia belongs to the family Ulmaridae, order Semaeostomeae, class Scyphozoa (Kramp 1961). Aurelia is the best studied of all scyphozoans, yet its taxonomy and evolution are still under discussion (Dawson and Jacobs 2001). The cosmopolitan moon jelly Aurelia is characterized by high degrees of morphological and ecological plasticity, and subsequently by an unclear taxonomic status. The latter has been revised repeatedly over the last century, dividing the genus Aurelia into as many as 12 or as little as two species (Schroth et al. 2002).

The degree of Aurelia morphological plasticity never influences the main medusa feature-huge mesoglea. Previously the new protein "mesoglein" was determined as one of the main components of mesoglea. Mesoglein mRNA cloned sequence is 1421 bp long. The deduced amino acid (aa) sequence of 416 aa contains Zona Pellucida (ZP) domain and Delta/Serrate/Lag-2 domain. According to reverse transcription PCR, mesoglein is expressed in the mature medusa exclusively in the mesogleal cells (Matveev et al. 2007). The presence of the $\mathrm{ZP}$ domain in mesoglein allows to consider it as a member of the big family of ZP domaincontaining proteins, which includes more than a thousand known members. The domain is thought to mediate the formation of extracellular protein fibers or meshworks (Jovine et al. 2005), which is in full agreement with mesoglein's position in the mesoglea (Shaposhnikova et al. 2005). The name of the family originates from Zona Pellucida, which is built up of ZP domain proteins and play crucial role in fertilization (Bork and Sander 1992).

Autoradiographic analysis and immunostaining indicate that Mc are typical protein-synthesizing cells (Napara et al. 1996). Immuno staining demonstrates the presence of the mesoglein in Mc granules and in the mesoglea "elastic" fibers; apical part of the ectodermal cell is also stained. So, it is confirmed by several techniques that Mc synthesize and excrete the main mesoglea protein which is included in the "elastic" fibers (Shaposhnikova et al. 2005).

Comparison mesogleins of medusas from White Sea (WsA), Black Sea (BsA) and Japonic Sea (JsA) has been the aim of the current work. Based on morphological data the bulk of original species is summarized as a single species, A. aurita, which is deemed to be an ecological generalist and occupy worldwide habitats of all but north polar oceans. (Schroth et al. 2002). According to this assumption we did not expect to find dramatic differences in mesoglea composition but it happens not to be so.

\section{Materials and methods}

Animals

A. aurita medusas were collected in the vicinity of the Hydrobiological Station of Odessa I.I.Mechnikov national university, Black Sea (BsA); Marine Biologcal Station "Vostok" of AV Zhirmunsky Institute of Marine Biology, Japan Sea (JsA); the White Sea Biological Station of the Zoological Institute RAS "Kartesh" (Chupa Inlet, Kandalaksha Bay in the White Sea (WsA) (http://www.zin.ru/kartesh/default_en.asp) during the summers of 2009-2013. The methods of mesoglea and mesogleal cells (Mc) isolation have been published (Shaposhnikova et al. 2005). 
SDS electrophoresis and immunoblot

Mesoglea polypeptides were separated by SDS-PAGE (Laemmli 1970). Acrylamide concentration was from 7 to $10 \%$ in gels. Gels were stained with $0.1 \%$ Coomassie Brilliant Blue R-250.

Polypeptides separated by SDS-PAGE were transferred to polyvinylidene difluoride (PVDF, Sigma, USA) membrane or nitrocellulose membrane (Sigma) in a Trans-blot (Towbin et al. 1979). The membranes were blocked with $5 \%$ skimmed milk at PBS-Tw for $1 \mathrm{~h}$ or overnight. The membrane was then immersed in PBSTw with Gpames-a (1:5000 dilution) for $1 \mathrm{~h}$, then washed with PBS-Tw three times. The secondary antibody commercial stock (GAGp-HRP, Sigma, USA) was diluted 1/10,000 (v:v) in TBS-Tw. After incubation for $1 \mathrm{~h}$ at room temperature with shaking, the membranes were washed twice with PBS-Tw (10 min each). Finally, the sites of enzyme binding were developed with DAP- $\mathrm{H}_{2} \mathrm{O}_{2}$. All operations were carried out at room temperature with shaking. Guinea pig pre-immune serum instead of Gpames-a was used as the control and it did not produce any signal.

AU electrophoresis and antibodies production

Mesoglein is a charged protein so acid-urea polyacrylamide gel electrophoresis (AU-PAGE; Podgornaya and Shaposhikova 1998; Waterborg 2002) was used to separate the protein for immunization. Acrylamide concentration in gels was $7 \%$. Gels were stained with $0.1 \%$ Coomassie Brilliant Blue R-250.

New polyclonal serum with antibodies against mesoglein of Aurelia aurita (WsA) was obtained. In this paper, it is named Gpames-a (Guinea pig anti-mesoglein from AU-PAGE). Mesoglein was cut out from the slab gel, homogenized with $0.9 \% \mathrm{NaCl}$ and mixed with Freund adjuvant (1:1); this mixture was injected hypodermically into male Guinea pig. Boosting with the same mixture was performed intramuscularly in 3 weeks. A week later about $8 \mathrm{ml}$ of blood was taken from the Guinea pig's heart. The antiserums were mixed with glycerol (1:1) and $0.02 \% \mathrm{NaN}_{3}$, aliquoted and stored at $-20{ }^{\circ} \mathrm{C}$. The samples of pre-immune serums were obtained from the same Guinea pig a week before antigen injection for control staining. The optimal working dilution of Gpames-a is 1:30,000 for immunoblots and 1:10,000/5000 for immunohistochemistry.

Immunohistochemistry

Small pieces (about $0.5 \mathrm{~cm}^{3}$ ) of medusa's body including ectodermal layer and mesoglea were fixed in $4 \%$ paraformaldehyde in filtered seawater for $24 \mathrm{~h}$ and rinsed sequentially in 30, 50 and $70 \%$ ethanol (for $1 \mathrm{~h}$ each). The fixed samples were embedded in paraffin blocks to be cut into 3-5- $\mu \mathrm{m}$-thick sections. The sections were preincubated with $5 \%$ skimmed milk in TBS-Tw for $1 \mathrm{~h}$, washed 4 times for 10 min with TBS-Tw, incubated with Gpames-a at 1:5000 dilution (for $1 \mathrm{~h}$ ), washed and incubated with HRP-conjugated goat-antiGuinea pig Ig (GAGp-HRP, Sigma), and visualized with microscope (Leica DM6000). For controls, some sections were incubated with non-immune GP serum followed by the same subsequent steps.

RNA isolation and cDNA synthesis

About $10 \mathrm{ml}$ mesoglea jellyfish from each population (BsA, JsA, WsA) was cut into pieces and treated with $1 \mathrm{mg} / \mathrm{ml}$ collagenase (ICN, cat $\mathrm{N} \mathrm{150705)} \mathrm{solution} \mathrm{in} \mathrm{sea} \mathrm{water} \mathrm{at} 37{ }^{\circ} \mathrm{C}$ for $30 \mathrm{~min}$. The suspension of mesogleal cells (Mc) was centrifuged at $800 \mathrm{~g}$ for $20 \mathrm{~min}$. Supernatant was discarded and RNA was isolated from pelleted cells by Trizol (Invitrogen) solution according to the manufacturer's instructions. RNA samples were treated with RNAse-free DNAse (Roche) to avoid DNA contamination. DNAse was removed by phenol:chloroform (2:1) extraction. About $1 \mu \mathrm{g}$ of the RNA was reverse transcribed using oligo-dT primer ( $5^{\prime}$ $\mathrm{T}(12-20) \mathrm{V}$ ) by MMLV RT kit (Evrogen) according to the manufacturer's recommendations. The RT reaction product was diluted fivefold and stored at $-20{ }^{\circ} \mathrm{C}$. For controls, PCR with primers GAPDH of Aurelia aurita (Aa_GAPDH_F: 5'caaattgccttgcacccttagcc; Aa_GAPDH_R: 5'gttctggaatgcaccacgtcca) were used. 
PCR amplification

All PCRs were amplified in $25 \mu \mathrm{l}$ reactions composed of $0.2 \mu \mathrm{M}$ mesoglein (WsA, GenBank: ABK88269.1; Matveev et al. 2007)-specific primers (Table 1), $2.5 \mu \mathrm{l}$ of $10 \times$ PCR buffer, $3 \mathrm{mM} \mathrm{MgCl} 2,0.2 \mathrm{mM} \mathrm{dNTPs,}$ and $0.1 \mu \mathrm{l}$ of Taq polymerase (Evrogen) on Eppendorf Mastercycler Personal 5332 Thermocycler. All PCRs began with a 5-min denaturation step at $94-95{ }^{\circ} \mathrm{C}$, followed by $25-30$ thermal cycles including a $94{ }^{\circ} \mathrm{C}$ for $20 \mathrm{~s}$ denaturation step, $57{ }^{\circ} \mathrm{C}$ for $20 \mathrm{~s}$ primer annealing and elongation step- $72{ }^{\circ} \mathrm{C}$ for $1.5 \mathrm{~min}$. All PCRs terminated with a 3-min extension step at $72{ }^{\circ} \mathrm{C}$ and refrigeration at $4{ }^{\circ} \mathrm{C}$ and immediately used for agarose electrophoresis.

\section{Results}

The total set of the main mesoglea proteins is similar in medusas from all habitats on SDS-PAGE. Medusas from White Sea (WsA) initial mesogleins' apparent molecular mass $\left(M_{r}\right)$ is $47 \mathrm{kDa}$ (Figs. 1a, 2 ; Matveev et al. 2007); same $M_{r}$ revealed for mesoglein of medusa from the Black Sea (BsA). Mesoglein of medusa from the Japonic Sea (JsA) differs: $M_{r}$ is $53 / 55 \mathrm{kDa}$ (Fig. 1a). At the next step we checked by immunoblot whether JsA mesoglein has the same antigenic determinants despite the $M_{r}$ difference. Antibodies Gpames-a against WsA mesoglein were used (Adonin et al. 2009). It happens that both BsA and WsA mesogleins do react with the antibodies, but there is no staining with any proteins in JsA mesoglea (Fig. 1b).

Same antibodies were used to reveal mesogleins' position on paraffin sections. Gpames is the newly obtained serum and it is visible that it stained Mc, "elastic" fibers inside mesoglea and apical parts of the ectodermal cells (Figs. 2, 1) according to the position already known (Shaposhnikova et al. 2005). Same picture of mesoglea staining was obtained for BsA, though the staining is completely absent on JsA sections (Fig. 2b).

The absence of the antibodies cross reactivity makes us suppose that the degree of the gene diversity could be quite high. To check it, we produce the set of primer pairs based on the known WsA mesoglein sequence. The primers are situated in mesogleins' different parts and expected to produce the product of counted length in PCR (Fig. 3). The primer sequences are given in Table 1 and primers 2,3,4 are directed to the functional mesogleins' part-its' ZP domain, primers 1 and 5 directed against flanked regions. Primers for WsA GAPDH gene were used as the control. cDNA from total polyA-RNA from Mc was used as the template for PCR.

The PCR results are shown in the Table 2. It happens that PCR products of the length expected appear only on cDNA templates of WsA and BsA but not on JsA. So, the difference between mesoglein is obvious not only at protein level but at the level of RNA as well. The divergence of mesoglein genes in Aurelia from different populations is high enough not to give products with primers based on mesoglein initial sequence.

Table 1 Mesoglein (WsA) specific primers

\begin{tabular}{lll}
\hline No. pairs & Primer name & $5^{\prime}-3^{\prime}$ primer sequence \\
\hline 1 & bDSL1_F & ACAGAAGAGGCCCCTGGTGCA \\
& bDSL1_R & TGCAAGCAAGAAAACGATGGAGACA \\
2 & ZP1_F & CCCGCATCAGCTTGAAGGACGA \\
& ZP1_R & ACTGGAATGCGCCAAATCCATCT \\
3 & ZP2_F & GGATTCAGCACCACAGAATTGTGGA \\
& ZP2_R & GCGTTCCATGGTAGGTGTTGCAT \\
4 & ZP3_F & GCAACACCTACCATGGAACGCA \\
5 & ZP3_R & TCACCGCCAGCGTAGCTTGAA \\
& aZP_F & TGGTCGCTGGAGTCTGCAGTC \\
\hline
\end{tabular}


Fig. 1 Mesogleas' protein composition on SDS-PAGE (a) and immunoblot with Gpames-a against WsA mesoglein (b). $M_{\boldsymbol{r}}$ in $\mathrm{kDa}$ of the marker proteins is given at the left. Mesoglea of medusa from JsA -1 , WsA-2,

BsA-3. Mesoglein staining is visible on 2 and 3 but not 1 on $\mathbf{b}$
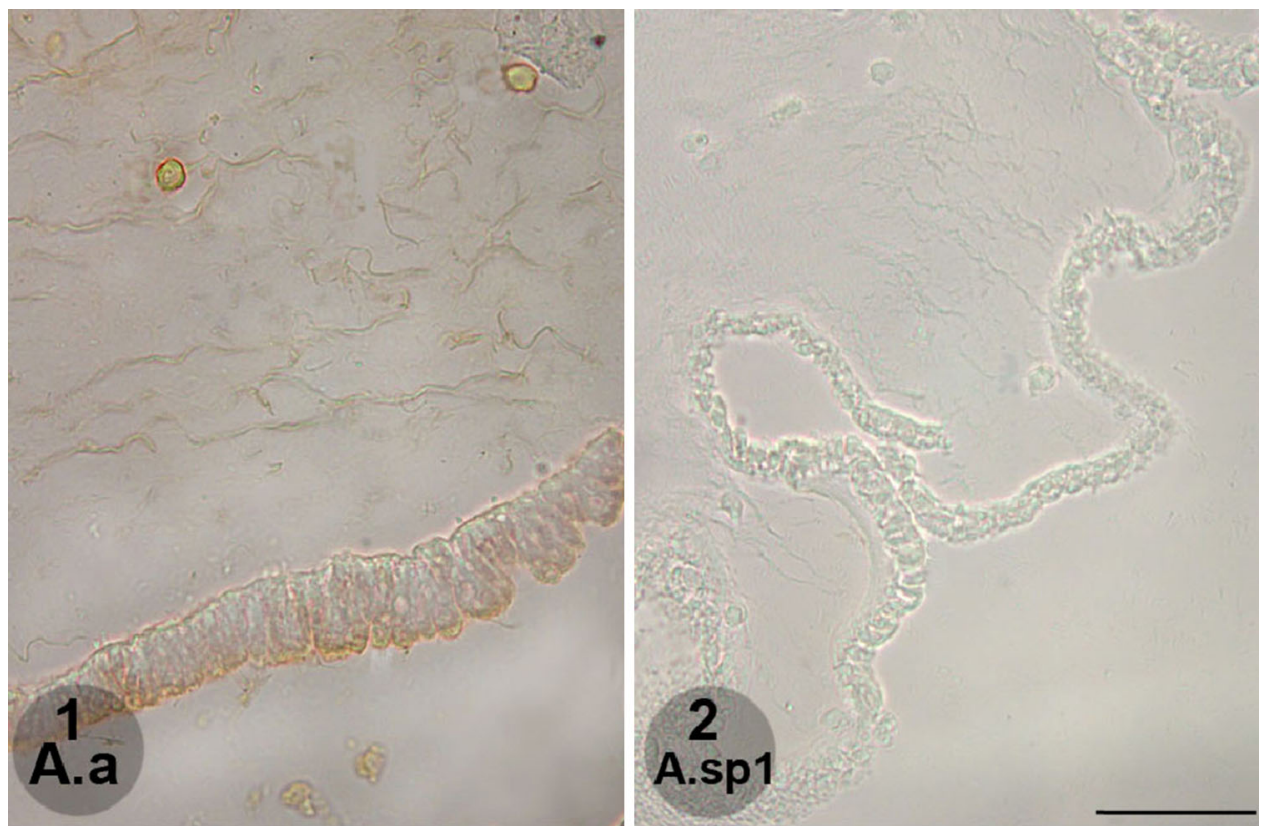

Fig. 2 Immunocytochemistry staining with Gpames-a antibodies on paraffin sections of WsA medusa (1) and JsA (2). Bar $50 \mu \mathrm{m}$

\section{Discussion}

The jellyfish Aurelia aurita (Linnaeus 1758) is usually considered to be a cosmopolitan species. Ecological differentiation in populations may force diversification and speciation (Schluter 1996) and it has to be determined whether phenotypic variation correlates to genetic and reproductive isolation. In marine environments invertebrate taxa in general show weak genetic structuring due to large population sizes, high larval 


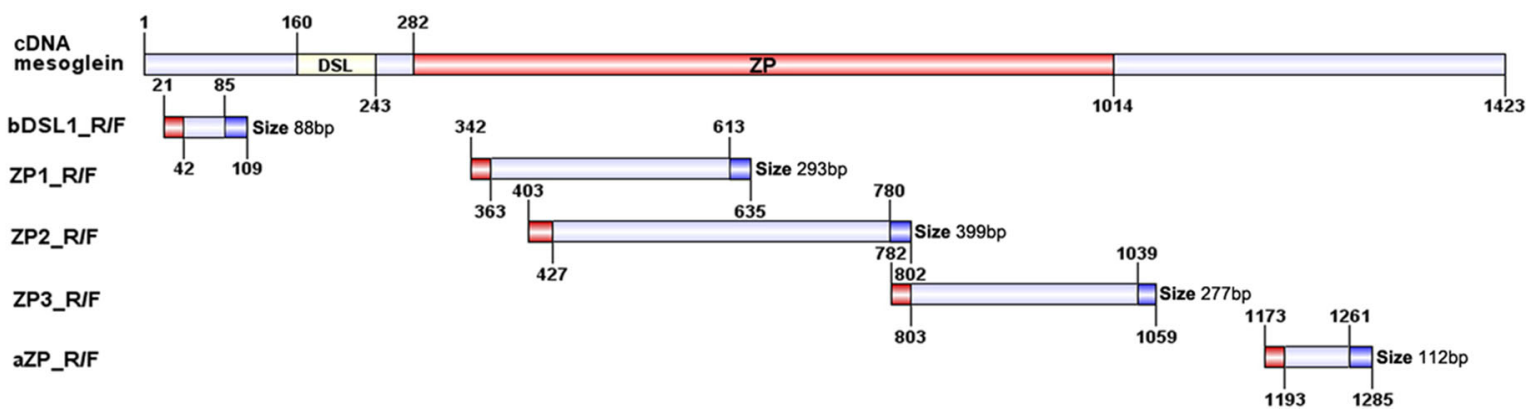

Fig. 3 Scheme of the mesoglein cDNA with the domain indicated and position of the pairs of primers. Primers' names are given according to the Table 1, first and last nucleotide position of each primer is indicated, lines between primers indicate the PCR product of the length counted

Table 2 PCR products obtained on Mc cDNA from medusas of three populations

\begin{tabular}{lllllll}
\hline Template & \multicolumn{2}{l}{ Primer pairs } & & & \\
\cline { 2 - 6 } & 1 & 2 & 3 & 4 & 5 & GAPDH \\
\hline WsA & + & + & + & + & + & + \\
BsA & + & + & + & + & + & + \\
JsA & - & - & - & - & + & + \\
\hline
\end{tabular}

Ns of primer pairs are given according to Table 1. (+) product of expected length, $(-)$ no product

dispersal capacities, the lack of physical barriers, and sometimes interspecific hybridization (Palumbi 1992; Gosling 1994). (Schroth et al. 2002). Designating a species status can be a problematic task and the underlying concepts are subject of ongoing discussions (e.g., Templeton 1998; Avise 2000; Schroth et al. 2002).

At the beginning of the twentieth century there were three Aurelia species-A. aurita, A. labiata, A. solida (Mayer 1910). In the middle of the twentieth century seven species were separated: A. aurita, A. coerulea, A. colpota, A. labiata, A. limbata, A. solida, Aurelia spp. (Kramp 1961). Next decade brings up new classification-only two species were counted as established: A. aurita and A. limbata (Russell 1970). The rest of the species were combined in A. aurita. At the end of the century again one of the species from "Synopsis of the medusae of the world" (Kramp 1961), namely A. labiata, came back (Wrobel and Mills 1998).

The end of the century and, moreover, twenty-first century brings up molecular biology methods. In allozyme electrophoresis, significant differences at 12 of 14 polymorphic loci strongly suggest that Aurelia sp. from Foster City and Tokyo Bay belong to one species, while Aurelia sp. from Monterey Bay and Vancouver Island belong to a second species. The identities and taxonomic affinities of the two Aurelia defined in this study, and their relationships with the Linnaean A. aurita described from the North Atlantic, will require genetic and morphological study of the currently recognized species A. aurita and A. limbata (Brandt 1838) from several zoogeographical provinces. Nevertheless, on the protein level two groups, probably species, was distinguished-North American and Asian (Greenberg et al. 1996).

The sequencing approach again makes the story more complicated. Molecular phylogeny of Aurelia was built up on the base of nuclear ribosomal DNA (nrDNA), mitochondrial $16 \mathrm{~S}$ and mitochondrial cytochrome $c$ oxidase subunit I (COI) (Dawson 2003). A. limbata and A. labiata were defined as distinct species, but $A$. aurita was divided into 11 cryptic species A.sp.1-A.sp.11 (Fig. 4) (Dawson and Jacobs 2001).

The name A. aurita was saved to the initial population described by Linnaeus at the European North coast (Dawson 2003; Dawson et al. 2005). Comparison of mitochondrial and nuclear DNA data (16S and ITS-1/5.8S rDNA) strongly suggests historic speciation events and the reconstruction of at least seven different species within Aurelia. This type of analysis reveals the Aurelia similarity according to climatic zones defined by minimum (winter) surface water temperatures: boreal $0-8{ }^{\circ} \mathrm{C}$ (West-Atlantic, East-Atlantic/Northern Sea/ Baltic Sea, and Black Sea) and temperate-mediterranean 8-19 ${ }^{\circ} \mathrm{C}$ (Mediterranean locations, Australia, Japan, and American Pacific) (Schroth et al. 2002). 


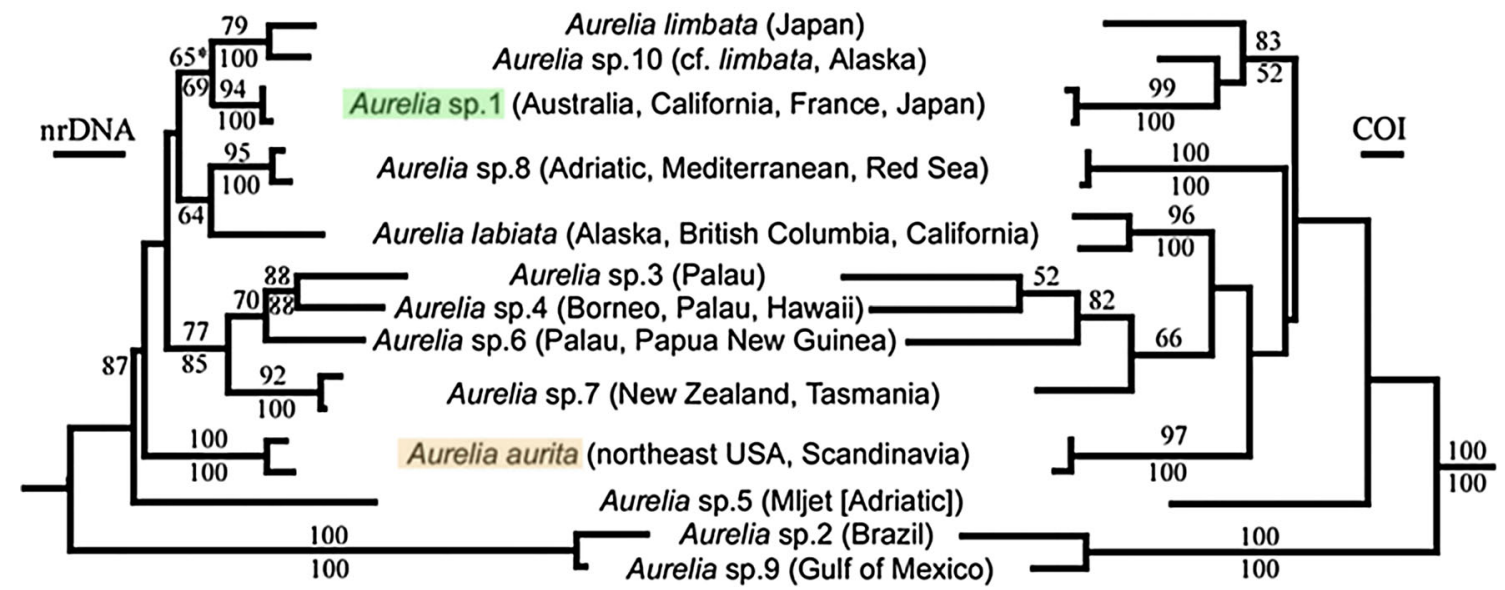

Fig. 4 Molecular phylogeny of Aurelia with maximum likelihood nrDNA and COI gene trees (Dawson et al. 2005, changed). Aurelia aurita (WsA) is in orange rectangle, Aurelia sp. 1 (JsA) is in green frame

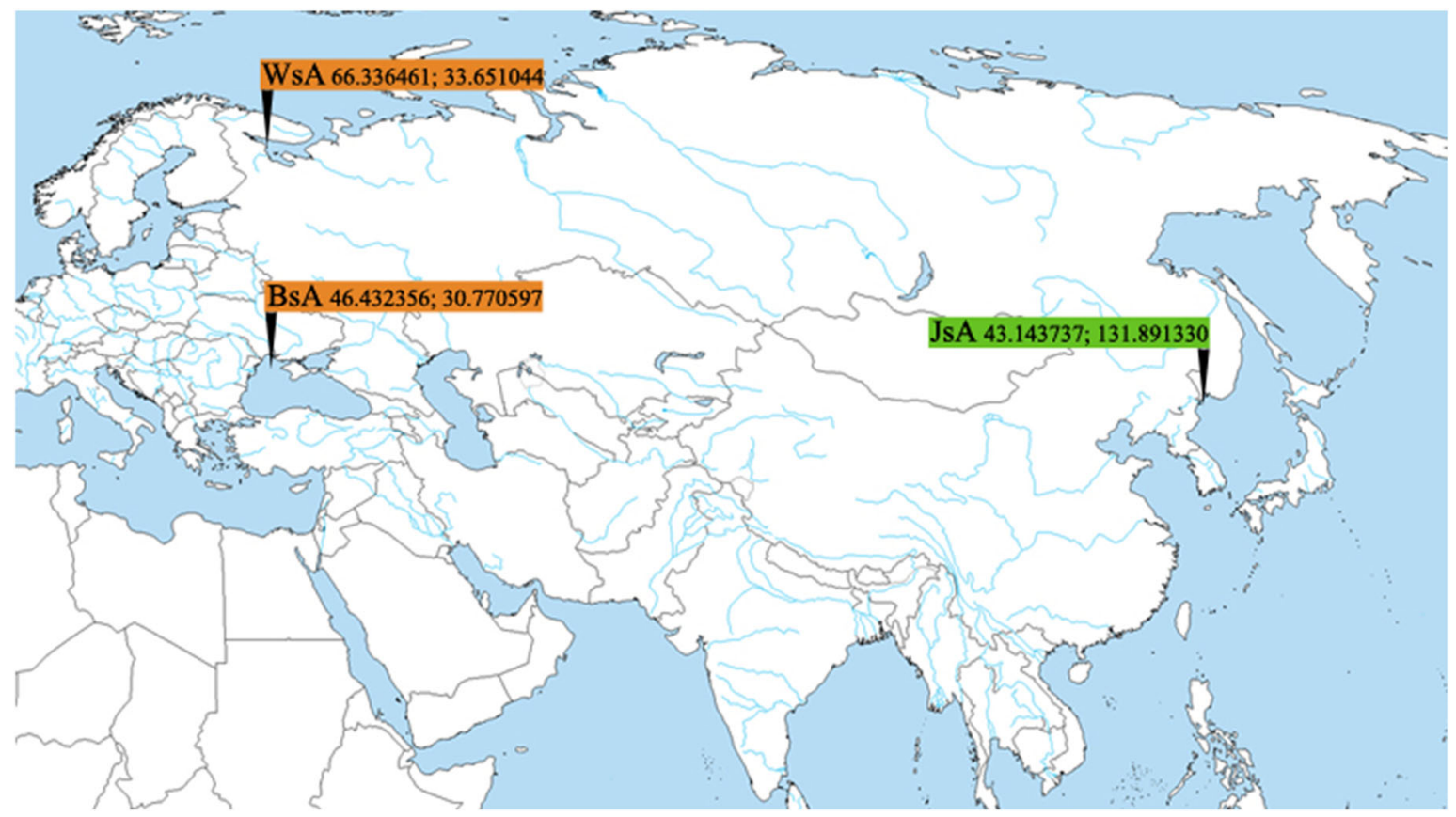

Fig. 5 Schematic representation of Aurelia distribution according to difference in mesoglein. Orange flags-WsA and BsA, Aurelia aurita; green flag_-JsA, Aurelia sp.1. Species names are according to Fig. 4 (Dawson et al. 2005)

All species of genus Aurelia possess prominent mesoglea, i.e., extracellular matrix (ECM). At the morphological level two types of fibers, which are embedded in a jelly-like ground substance, have been described in cnidarians mesoglea: collagen-like and the so-called "elastic" or vertical fibers (Chapman 1959; Elder 1973; Bouillon and Coppois 1977; Weber and Schmid 1985). Medusa locomotion is attained by muscular contractions of the bell margin when water is ejected from the oral surface and the animal is propelled in the aboral direction, while the recovery is affected by elastic recoil of the mesoglea (Naumov 1961; Tardent 1978). Mesoglein is one of the main mesoglea ECM proteins and the essential component of the elastic fibers (Shaposhnikova et al. 2005; Matveev et al. 2007). It was reasonable to suppose that it is a conservative protein, especially due to its ZP domain. ZP proteins are quite an ancient purchase in the evolution: they are found even in Trichoplax genome (Matveev et al. 2012) not to mention their key role in fertilization (Jovine et al. 
2005; Adonin et al. 2012). Surprisingly, we found differences at the level of $M_{r}$, (Fig. 1a), in immunoreactivity (Figs. 1b, 2) and in mesoglein gene cDNA (Table 2). The difference in sequence affects not only flanking sequences but ZP domain itself. The mesoglein gene from JsA is under cloning now to clarify the degree of diversity. Mesoglein comparison produced clear difference of two Aurelia populations: WsA and BsA belong to the boreal area, while JsA separated from its (Fig. 5).

Though one protein analysis is not enough to distinguish the species, at least two of them could be expected due to our data. Most of the contemporary animal groups appear for the first time in the fossil record some 545 million years ago (MYR) on the geological time scale in a relatively short period of time known as the Cambrian explosion (Benton and Harper 2009). Cnidaria could be even older for they could not leave the fossil record. Cnidaria do not disappear in the Permian extinction ( 300 MYR) but continue their evolution. Aurelia's complex life cycle consists of several stages including alternating generations of sexual adult-stage medusa and asexual-stage polyp (scyphistoma) sitting at the sea bottom. Medusas also prefer coastal waters (Naumov 1961; Tardent 1978). So, the history of the Earth coasts is important for medusa evolution. At the board of the Jurassic and Cretaceous in Mesozoic about 150 MYR ago, the gradual rifting of the supercontinent Pangaea into separate landmasses that would eventually move into their current positions occurs. The Mesozoic was a time of significant tectonic, climate and evolutionary activity, which leads to the separation of the two oceans-Atlantic and Pacific. These two groups of genus Aurelia are clearly visible both in the current research and previously published (Greenberg et al. 1996; Schroth et al. 2002). BsA also belongs to the Atlantic population.

Genus Aurelia as the taxon has traditionally experienced difficulties in demarcating species boundaries (Schroth et al. 2002). The compound action of hybridization and temperature-dependent adaptations could contribute to the formation of the high species richness in Aurelia, but our data and the data previously published rather evidenced for the historically formed several groups, two of which (Atlantic and Pacific) are included in the present study. The traditional methods of molecular phylogeny analysis are necessary to confirm the existence of such groups and, probably, the precise species will be distinguished at the end.

Acknowledgments This work was supported by the Russian Foundation for Basic Research (grants 02-04-49420-a, 05-0449578-a, 09-04-01145-a, 13-04-01739-a) and grant from presidium RAS (MCB).

Open Access This article is distributed under the terms of the Creative Commons Attribution License which permits any use, distribution, and reproduction in any medium, provided the original author(s) and the source are credited.

\section{References}

Adonin LS, Podgornaya OI, Matveev IV, Shaposhnikova TG (2009) Plate in the zone of oocyte and germinal epithelium contact in Scyphomedusa Aurelia aurita binds antibodies to ZP-domain protein mesoglein. Cell Tissue Biol 3(3):283-288

Adonin LS, Shaposhnikova TG, Podgornaya OI (2012) Aurelia aurita (Cnidaria) Oocytes contact plate structure and development. PLoS One 7(11):e46542

Arai MN (1997) A functional biology of scyphozoa. Chapman and Hall, London, pp 28-206

Avise JC (2000) Phylogeography. The history and formation of species. Harvard University Press, Cambridge, p 464

Benton MJ, Harper DAT (2009) Introduction to paleobiology and the fossil record. Wiley-Blackwell, Hoboken, p 608

Bork P, Sander (1992) A large domain common to sperm receptors (Zp2 and Zp3) and TGF-beta type III receptor. FEBS Lett 300:237-240

Bouillon J, Coppois G (1977) Etude comparative de la mesoglée des cnidaires. Cah Biol Mar 18(1-3):339

Chapman G (1959) The mesoglea of Pelagia noctiluca. Q J Microsc Sci 100:599-610

Chapman G (1966) The structure and function of the mesoglea. In: The cnidaria and their evolution. London: Acad. Press. pp 147-168

Chapman DM (1974) Cnidarian histology. In: Coelenterate biology. Reviews and new perspectives. New York. Acad. Press. pp 1-93

Daly M, Brugler MR, Cartwright P, Collins AG, Dawson MN, Fautin DG, France SC, McFadden C, Opresko DM, Rodrigues E, Romano SL, Stake JL (2007) The phylum Cnidaria: a review of phylogenetic patterns and diversity 300 years after Linnaeus. Zootaxa 1668:127-182

Dawson MN (2003) Macro-morphological variation among cryptic species of the moon jellyfish, Aurelia (Cnidaria:Scyphozoa). Mar Biol 143(2):369-379

Dawson MN, Jacobs DK (2001) Molecular evidence for cryptic species of Aurelia aurita (Cnidaria, Scyphozoa). Biol Bull 200:92-96

Dawson MN, Gupta AS, England MH (2005) Coupled biophysical global ocean model and molecular genetic analyses identify multiple introductions of cryptogenic species. Proc Natl Acad Sci USA 102(34):11968-11973 
Dogel VA (1981) Zoology of invertebrates. M., Vysshaya Shkola [in Russian]

Elder HY (1973) Distribution and functions of elastic fibers in the invertebrates. Biol Bull 144:43-63

Gosling EM (1994) Speciation and species concepts in the marine environment. In: Genetics and evolution of aquatic organisms. London, Chapman \& Hall. p 539

Greenberg N, Garthwaite RL, Potts DC (1996) Allozyme and morphological evidence for a newly introduced species of Aurelia in San Francisco Bay, California. Mar Biol 125(2):401-410

Hyman LH (1940) The invertebrates, Vol. 1. Protozoa through ctenophora. McGraw Hill, New York, p 726

Jovine L, Costel CD, Litscher ES, Wassarman PM (2005) Zona pellucida domain proteins. Annu Rev Biochem 74:83-114

Kayal E, Roure B, Philippe H, Collins AG, Lavrov DV (2013) Cnidarian phylogenetic relationships as revealed by mitogenomics. BMC Evol Biol 13(1):5

Kramp PL (1961) Synopsis of the medusae of the world. J Mar Biol Soc UK 40:1-469

Laemmli UK (1970) Cleavage of structural proteins during the assembly of the head of bacteriophage T4. Nature 227(5259):680-685

Linnaeus C (1758) Systema naturae (Ed. 10), vol. 1. Salvii, Holmiae. 824 p

Matveev IV, Shaposhnikova TG, Podgornaya OI (2007) A novel Aurelia aurita protein mesoglein contains DSL and ZP domains. Gene 399:20-25

Matveev IV, Adonin LS, Shaposhnikova TG, Podgornaya OI (2012) Aurelia aurita-cnidarian with a prominent medusoid stage. J Exp Zool Part B Mol Dev Evol 318(1):1-12

Mayer AG (1910) Medusae of the World: the scyphomedusae. Carnegie institution of Washington, Washington, p 735

Napara TO, Oskol'sky AA, Shaposhnikova TG, Chaga OY (1996) Mesogleal cells of Aurelia aurita (Cnidaria:Scyphozoa) III. An autoradiographic analysis of the synthesis of extracellular matrix of mesoglea. Tsitologiya 38(4/5):465-474

Naumov DV (1961) Scyphomedusae of the seas of the USSR. Opred Faune SSSR 75:1-98 [in Russian]

Palumbi SR (1992) Marine speciation on a small planet. Trends Ecol Evol 7:114-117

Podgornaya OI, Shaposhikova TG (1998) Antibodies with the cell-type specificity to the morula cells from haemolymph of ascidian Styela rustica. Cell Struct Funct 23:349-355

Russell FS (1970) The Medusae of the British Isles volume II:pelagic scyphozoa, with a supplement to the first volume of Hydromedusae. Cambrige University Press, New York 284

Schluter D (1996) Ecological causes of adaptive radiation. Am Nat 148:40-64

Schroth W, Jarms G, Streit B, Schierwater B (2002) Speciation and phylogeography in the cosmopolitan marine moon jelly Aurelia sp. Biomed Cent Evolut Biol 2:1-10

Shaposhnikova T, Matveev I, Napara T, Podgornaya O (2005) Mesogleal cells of the jellyfish Aurelia aurita are involved in the formation of mesogleal fibres. Cell Biol Int 29:952-958

Tardent P (1978) Coelenterata, Cnidaria. In: Seidel T (ed) Morphogenesis der Tiere. Gustav Fischer Verlag, New York, pp 71-391

Templeton AR (1998) The role of molecular genetics in speciation studies. Molecular approaches to ecology and evolution. Birkhauser Verlag, Berlin, pp 131-156

Towbin H, Staehelin T, Gordon J (1979) Electrophoretic transfer of proteins from polyacrylamide gels to nitrocellulose sheets: procedure and some applications. Proc Natl Acad Sci 76(9):4350-4354

Waterborg JH (2002) The protein protocols handbook. Humana Press, New Jersey, pp 7-9

Weber C, Schmid V (1985) The fibrous system in the extracellular matrix of hydromedusae. Tissue Cell 17:811-822

Wrobel D, Mills C (1998) Pacific coast pelagic invertebrates:a guide to the common gelatinous animals. Sea Challengers, Monterey $108 \mathrm{p}$ 